\title{
On the Types of the Marginal Growth in Dicotyledonous Foliage Leaves*
}

\author{
by Noboru HARA** \\ 原＼cjkstart襄**：双子葉植物の普通葉に挌ける葉縁生長の型について*
}

Received December 15, 1956

Reports concerning the marginal growth of dicotyledonous leaves were reviewed thoroughly by Foster (1949) and Esau (1953). According to Foster (1936, cf. Foster, 1937), the results obtained by the previous investigators indicate a general agreement in one important point-viz., the outermost layer of cells at the leaf margin represents an independent histogen which corresponds in its growth and anticlinal plane of cell division to "dermatogen" and marginal initials give rise solely to the epidermis. In subsequent reports (e.g. Girolami, 1954) this fact is also invariable so far as it concerns the ordinary leaves of dicotyledons. Inside marginal initials of these leaves submarginal ones are generally observed, and their types were discussed by many workers. Foster (1936, cf. Esau, 1953) showed two types, that is, in the first type, submarginal initials contribute to the formation of the adaxial, middle, and abaxial layers, and the middle one further gives rise to the middle mesophyll and the procambium, while in the second type, they form only the adaxial and abaxial layers, and the latter one gives rise to the middle layer which further differentiates into the middle mesophyll and the procambium. Gifford (1951) found a different type***, on the basis of Drimys Winteri var. chilensis, in which submarginal initials produce at first the adaxial and abaxial layers, and the adaxial layer gives rise to the middle layer which further differentiates into the middle mesophyll and the procambium. On the other hand, Schneider (1952) recognized two types, that is, PA- and ZS-Types. In the former, submarginal initials divide in periclinal and anticlinal planes, while in the latter, they divide only in oblique plane.

In these reports concerning the marginal growth in dicotyledonous leaves, exceptions were observed by Renner (1936) and Renner and Voss (1942, cf. Esau, 1953) in certain variegated leaves such as those of Sambucus nigra, Veronica gentianoides and Pelargonium zonale. In these cases periclinal divisions in the protoderm may produce white margins, but no such evidence is observed in normal green leaves in these species. In variegated leaves of Daphne odora and Fragaria chiloensis this fact has been also suggested by Imai (1936), though he submitted no such histogenetic evidence as Renner's observation. Although Foster (1937) reported in bud scales of certain

* Contributions from the Division of Plant Morphology, Botanical Institute, Faculty of Science, University of Tokyo, N.S. No. 79.

** Botanical Institute, Faculty of Science, University of Tokyo. 東京大学理学部植物学教窒

*** In monocotyledons, the same type was observed in maize leaf by Mericle (1950). 
species of Rhododendron that marginal initials divide in oblique and periclinal planes, the process of development of the scale leaf is not always the same with that of the foliage leaf (cf. Cross, 1938). Thus, if our attention is restricted to the marginal growth of the dicotyledonous foliage leaf, exceptions are represented only by certain variegated leaves mentioned above.

Recently, the writer had an opportunity to observe the ordinary foliage leaf of Daphne odora of the Thymelaeaceae and found that the marginal growth in this leaf shows an exceptional type resembling certain variegated leaves in dicotyledons. Moreover, during the writer's studies on the structure of the shoot apex and the development of the leaf in the Ericaceae and its allies, he found that the marginal growth of the leaf of Tripetaleia paniculata shows the similar type to that of Drimys Winteri. These will be reported in this paper, and the developmental process of the marginal growth of a few other species in the Ericales will also be reported for the sake of comparison in discussing the standard types of the marginal growth of the dicotyledonous foliage leaves.

\section{Materials and Methods}

The leaves of Daphne odora Thunberg were obtained at the University of Tokyo, and those of Tripetaleia paniculata Sieb. et Zucc., Pieris japonica D. Don, and Clethra barbinervis Sieb. et Zucc. were obtained mainly in the Nikko Branch, Botanic Gardens of the University of Tokyo.

Materials were fixed in FAA, dehydrated in normal butyl alcohol, cut at $10 \mu$, and counterstained with haematoxylin and fast green.

In all cases median cross sections of leaves in various developmental stages were observed for comparison.

\section{Observations}

Daphne odora. As is shown in Fig. 1, the primordium of the leaf initiates from the shoot apex following the ordinary process of the dicotyledonous leaf. Before the marginal growth initiates, the protoderm surrounding the primordium undergoes here and there frequent periclinal divisions, which are not the ordinary feature of the dicotyledonous leaf. The initiation of the marginal growth is recognizable by protruding of marginal stripes on both sides of the adaxial part of the primordium. As soon as the marginal growth initiates, marginal initials re-

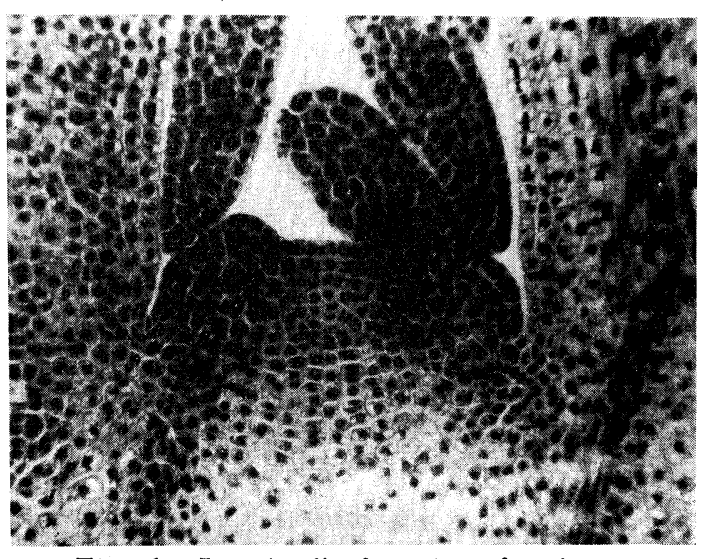

Fig. 1. Longitudinal section of a shoot apex of Daphne odora, with leaf primordia $(\times 150)$. 
peatedly divide in anticlinal plane to the leaf margin and give rise to the upper and lower protoderms (P1. III. A), the growth in surface of the protoderm being accomplished by the further anticlinal divisions and cell enlargement of their derivatives. The marginal initials, however, also divide very frequently in oblique plane, forming the biseriate margin (P1. III. B, F), and cells on the biseriate margin divide in periclinal plane to the leaf surface, forming inner layers of the leaf. Moreover, it is interesting enough that we can observe occasional periclinal divisions to the leaf margin in cells of marginal initials (Fig. 2. A, P1.III. C, G), and even periclinal ones to the leaf surface in protodermal cells closed to marginal initials (P1. III. D, H). So that, no stable submarginal initials are recognizable in this instance. In developing lamina, one or a few isolated mesophyll cells are often found in the biseriate margin (P1. III.E). These cells arise obviously from marginal initials or their derivatives.

Thus, the growth in inner layers as well as upper and lower protoderms is accomplished by the activity of marginal initials over the greater part of the leaf, excepting the median part of the leaf, which is considered to arise from the second cell layer of the shoot apex. The mature leaf has an uniseriate epidermis around the mesophyll, and has only a few vestiges of oblique divisions on its margin (P1. III. I).

A
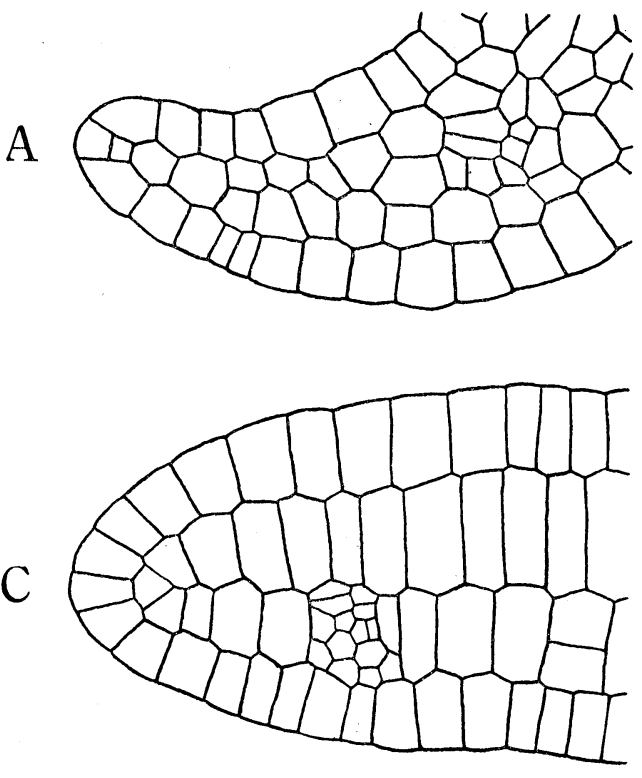

$\mathrm{B}$

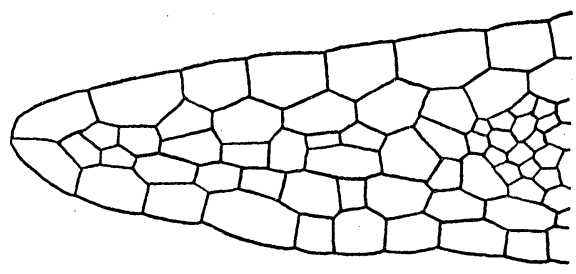

$\mathrm{D}$

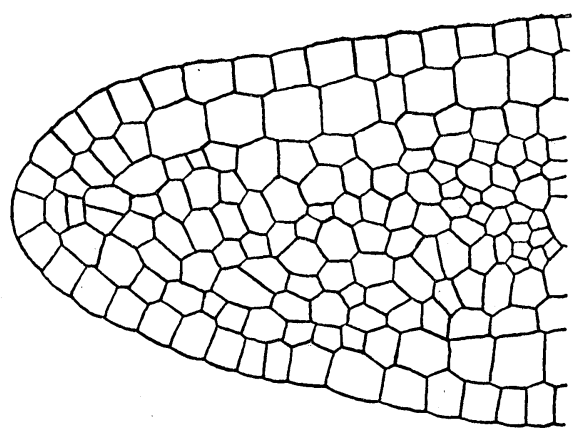

Fig. 2. Cross sections of the margins of the developing leaves. A. Daphne odora $(\times 400)$, B. Tripetaleia paniculata $(\times 350)$, C. Clethra barbinervis $(\times 400)$, D. Pieris japonica $(\times 500)$. The adaxial side of the leaf is shown in the upper side of the figure.

Tripetaleia paniculata. The initiation of the marginal growth can be obscurely recognized by the growth of marginal parts of the somewhat flattened cylindrical primordium. In this species there is no abnormal process of the marginal growth 
as in the case of Daphne odora, but marginal initials divide only in anticlinal plane to the leaf margin, and finally give rise only to the uniseriate upper and lower epidermis. Submarginal initials divide obliquely, giving rise to the adaxial and abaxial layers. Subsequent periclinal divisions occur mainly in the adaxial layer (Fig. 2. B), and this layer gives rise to the middle layer which further differentiates into the middle mesophyll and the procambium, though very rarely there are exceptional instances in which the abaxial layer partly concerns to supply the cells to the middle layer. The upper mesophyll arises from the adaxial layer, and the lower mesophyll arises from the abaxial layer.

Clethra barbinervis. The initiation of the marginal growth is recognizable by protruding of marginal stripes on both sides of the adaxial part of the primordium. As in the case of Tripetaleia paniculata, marginal initials produce the upper and lower protoderms, which give rise to the upper and lower epidermis respectively, and submarginal initials divide in oblique plane, giving rise to the adaxial and abaxial layers. But in this species the abaxial layer concerns the formation of the middle layer, which gives rise to the middle mesophyll and the procambium (Fig. 2. C). The upper mesophyll arises from the adaxial layer, and the lower mesophyll from the abaxial layer.

Pieris japonica. The initiation of the marginal growth and the activity of the marginal initials are the same in the case of Tripetaleia paniculata. Marginal initials produce only the upper and lower protoderms. But, submarginal initials divide in periclinal and anticlinal planes repeatedly. The adaxial and abaxial layers arise from submarginal initials by their anticlinal divisions in regard to the leaf margin, and the middle one, by their periclinal divisions (Fig 2. D). Because submarginal initials give rise to directly three inner layers and marginal initials give rise to the upper and lower protoderms, the margin of the leaf has five layers at the position of the third cell from the marginal initial one. For that reason and active divisions of the middle layer in anticlinal plane to the leaf margin, the form of the margin of the developing leaf is round in the cross section, while the margin of the leaf of the other species used in this study is comparatively tapered. The procambium and the middle mesophyll arise from the middle layer, the upper mesophyll from the adaxial layer, and the lower mesophyll from the abaxial layer.

\section{Summary and Discussion}

In Daphne odora it is certain that submarginal cells are frequently replaced by new cells derived from marginal initials without any stable submarginal initial. Although the distinct boundary between the parts derived from the first and the second cell layers of the shoot apex cannot be determined, it is also sure that the greater part of the mesophyll and the procambium arises from marginal initials, excepting the median part derived from the second cell layer of the shoot apex. Thus, we can observe in this species that marginal initials devide in oblique and periclinal planes 


\section{Diagrams}

MARGINAL TYPE (Fig.4, A)

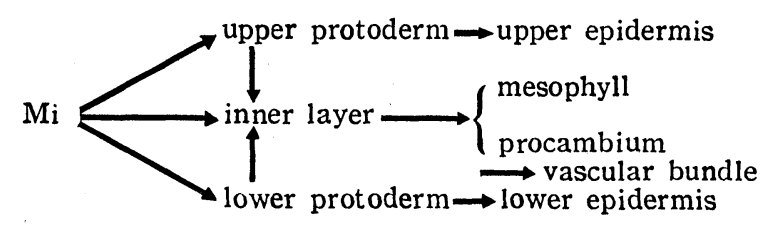

\section{SUBMARGINAL TYPE}

Adaxial Type (Fig. 4, B)

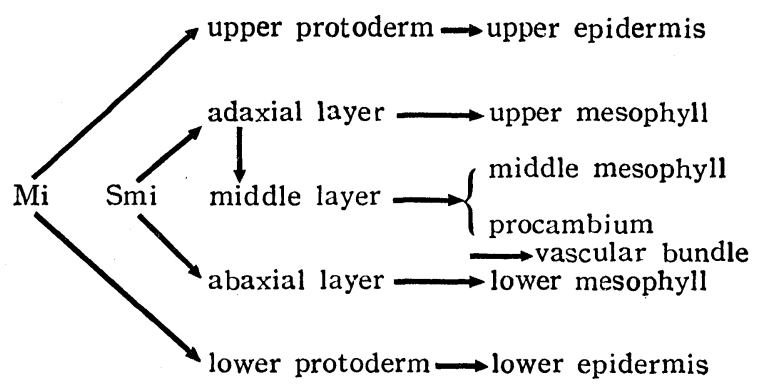

Abaxial Type (Fig. 4, C)

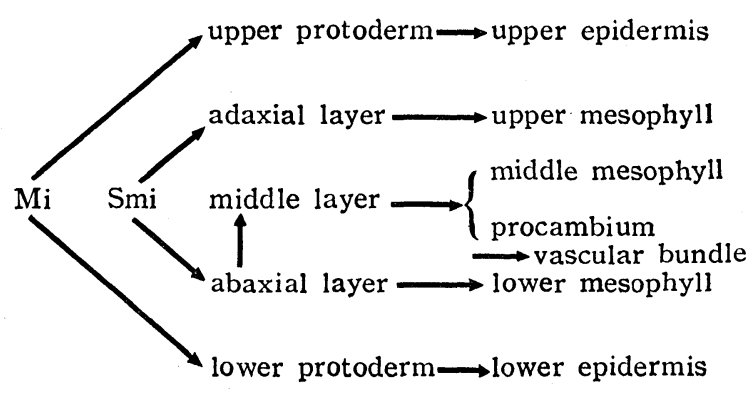

Middle Type (Fig. 4, D)

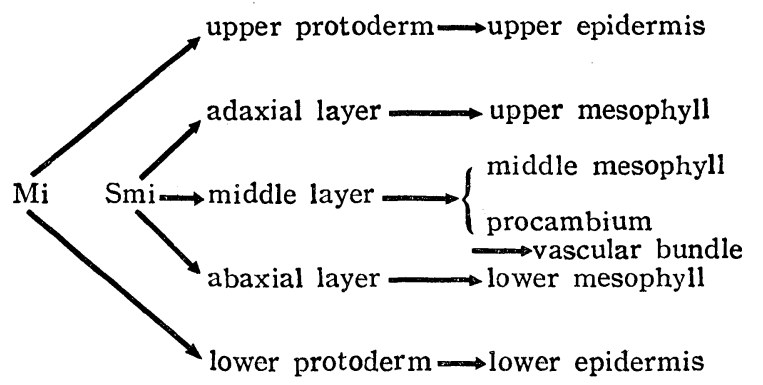

Examples

\section{Daphne odora}

Drimys Winteri (Gifford, 1951)

Tripetaleia paniculata

Carya buckleyi (Foster, 1935)

Morus alba (Cross, 1937)

\section{Linum usitatissimum}

Clethra barbinervis

(Girolami, 1954)

\author{
Pelargonium zonale \\ (Noack, 1922) \\ Nicotiana Tabacim \\ (Avery, 1933) \\ Gossypium hirsutum \\ (Gifford, 1953)
}

Fig. 3. Diagrams of types of the marginal growth. 
to the leaf margin from the first till the later stages of the marginal growth. The present report may be perhaps the first of this type in ordinary foliage leaves of dicotyledons, since such a case has not been reported by any author excepting in variegated leaves.

The type observed in Tripetaleia paniculata is the same with the case of Drimys Winteri var. chilensis observed for the first time by Gifford (1951), because the procambium arises from the middle layer derived from the adaxial layer. T. paniculata offers the second instance of this type in dicotyledons.

Clethra barbinervis and Pieris japonica show the common types of dicotyledons respectively, which have already been discussed by Foster (1936, cf. Esau, 1953).

The writer recognized that there exist two major types, the "marginal" type and the "submarginal" type, in regard to the marginal growth of the ordinary foliage leaves of dicotyledons according to the origin of the procambium. The submarginal type can be subdivided into three; the "adaxial", "abaxial", and "middle" types. The procambium arises from the adaxial layer in the first type, from the abaxial in the second type, and, in the third type, from the middle layer which arises from the submarginal initials directly. These patterns of the marginal growth are represented diagrammatically in Fig. 3 (cf. Fig. 4).

The leaf of one species shows, however, not always the only one type, but there

A

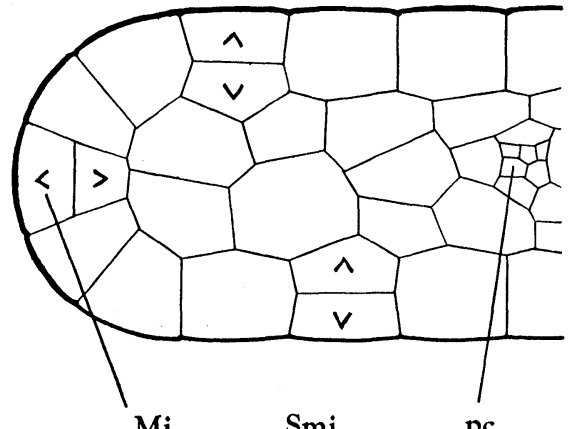

$\mathrm{C}$

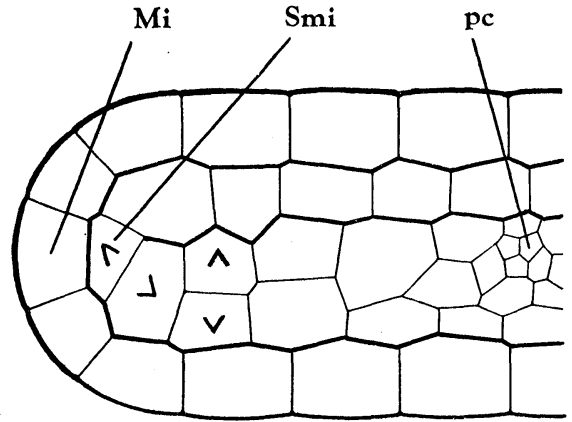

B

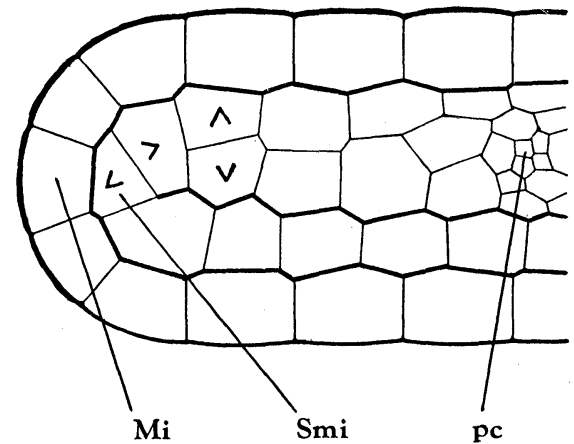

$\mathrm{D}$

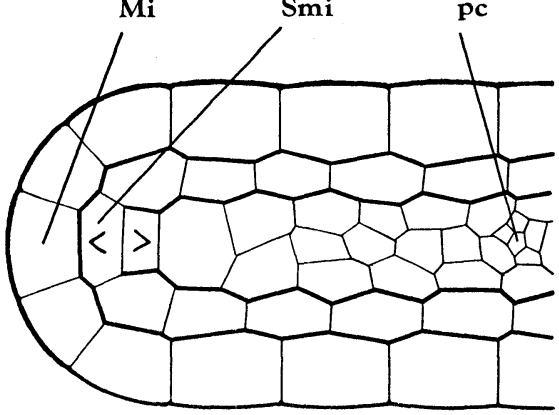

Fig. 4. Schematic representation of types of the marginal growth. A. Marginal Type, B-D. Submarginal Type, B. Adaxial Type, C. Abaxial Type, D. Middle Type, Mi: marginal initial cell, Smi: submarginal initial cell, pc: procambium. The adaxial side of the leaf is shown in the upper side of the figure. 
are fluctuations in developmental stages even in one and the same lamina, as shown by Gifford (1951) and Schneider (1952), and in parts of one lamina, as shown by Girolami (1954). Moreover the type of the marginal growth can be shifted experimentally, as shown by Gifford (1953). Cross (1937b, 1938) reported that there are many variations in the form of submarginal initials in different leaves or along the margin of the same leaf. These facts suggest the existence of some intermediate conditions between the abaxial and middle types, and the writer also recognizes some examples of intermediate types in his extensive study on the Ericaceae and its allies (unpublished).

The outermost layer of the leaf primordium of dicotyledons as well as the first tunica layer of shoot apex differentiates commonly into an independent histogen, which corresponds to "dermatogen", and the process of the marginal growth of these plants usually shows only the submarginal type. In this regard it is very interesting from the phylogenetic standpoint that Daphne odora shows the marginal type in its leaf development, which may possibly be considered as a primitive feature in the vascular plants.

The author wishes to express his best thanks to Em. Prof. Y. Ogura and Dr. S. Watari for their kind direction and advices. Thanks are also due to Mr. K. Kasahara for valuable suggestion concerning the leaf development of Daphne odora.

\section{Literature Cited}

Avery, G.S., Jr., Amer. Jour. Bot. 20: 565-592 (1933). Cross, G. L., Bull. Torrey Bot. Club 64 : 145-163 (1937a). Cross, G.L., Amer. Jour. Bot. $24: 266-276$ (1937b). Cross, G. L., Amer. Jour. Bot. 25 : 246--258 (1938). Esau, K., Plant anatomy, New York (1953). Foster, A. S., Amer. Jour. Bot. 22: 88-147 (1935). Foster, A.S., Bot. Rev. 2: 349-372 (1936). Foster, A. S., Amer. Jour. Bot. 24: 304-316 (1937). Foster, A.S, Practical plant anatomy, 2nd ed. New York (1949). Imai, Y., Zschr. f. ind. Abst. u. Vererbungslehre 71: 61-83 (1936). Gifford, E. M., Jr., Amer. Jour. Bot. 38: 93-105 (1951). Gifford, E. M., Jr., Hilgardia 21: 606-644 (1953). Girolami, G., Amer, Jour. Bot. 41 : 264-273 (1954). Mericle, L. W., Amer. Jour. Bot. 37 : 100-116 (1950). Noack, K. L., Jahrb. Wiss. Bot. 61: 459-534 (1922). Renner, O., Flora 130: 454-466 (1936). Renner, O. and M. Voss., Flora 135: 356-376 (1942). Schneider, R., Österr. Bot. Zeitschr. 99 : 253-285 (1952). 

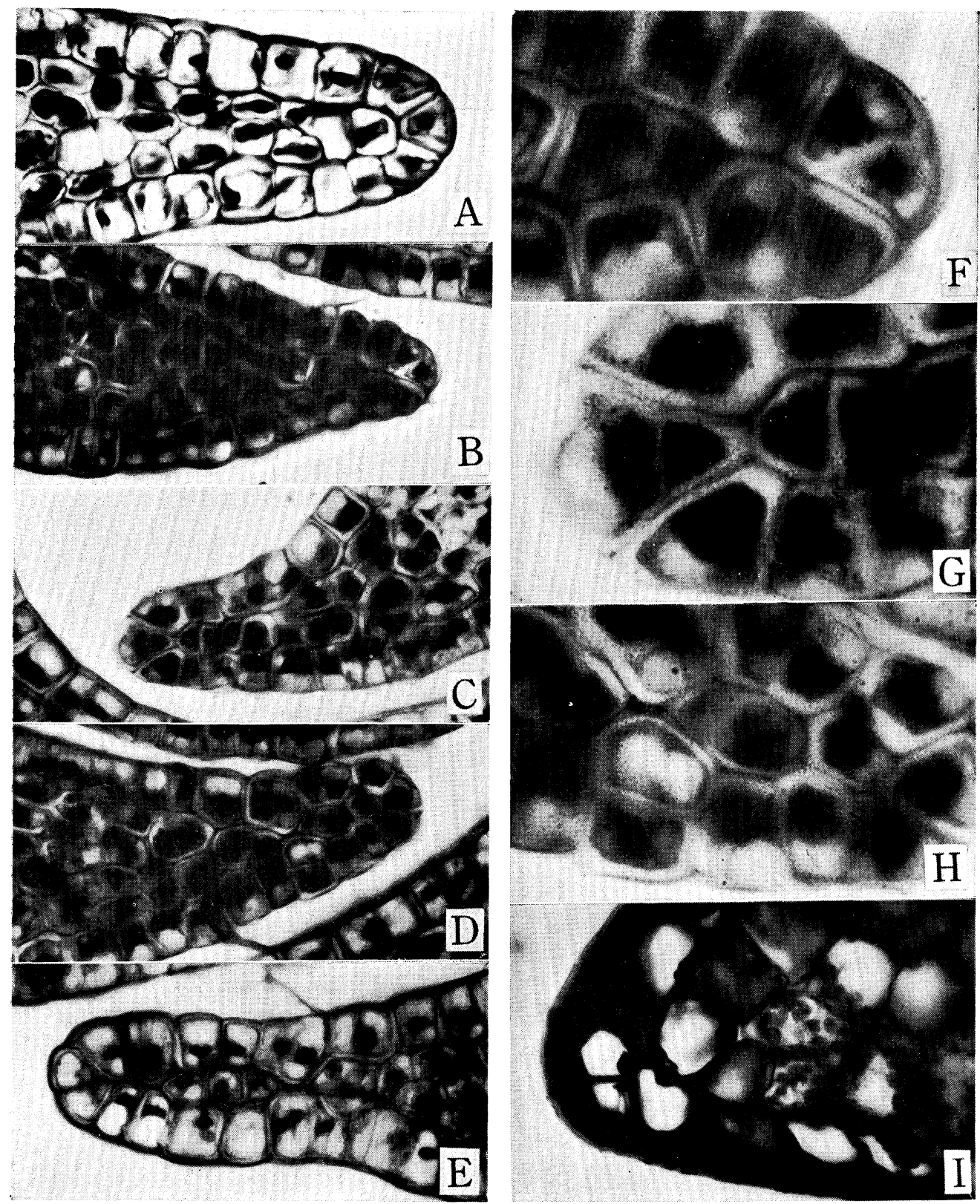

Plate III. Cross sections of leaves of Daphne odora (A-H: young developing leaves, I: mature leaf). The adaxial side of the leaf is shown in the upper side of the figure. $A(\times 350)$ : ordinary form of the margin in dicotyledons. $B(\times 400)$, $F($ enlargement of $B, \times 1200)$ : oblique division of marginal initial cell, forming biseriate margin, $C(\times 400)$, G(enlargement of $C, \times 1200)$ : periclinal division of marginal initial cell, $\mathrm{D}(\times 400), \mathrm{H}($ enlargement of $\mathrm{D}, \times 1200)$ : periclinal divisions of derivatives from marginal initials, $E(\times 400)$ : a few isolated mesophyll cells in biseriate margin, $\mathrm{I}(\times 350)$ : a vestige of oblique division of marginal initial cell.

N. Hara: On the types of the marginal growth in dicotyledonous foliage leaves. 